\section{White-Rumped Sandpipers}

\author{
Judge L. T. McKim
}

$\mathrm{O}^{\mathrm{N}}$ THURSDAY, May 17, Mrs. McKim and I, while canoeing on -Waterhen Marsh, saw four Hudsonian Godwits, and on the following Sunday, while driving, observed about 200 White-rumped Sandpipers.

The latter species has rarely been recorded here. Arthur C. Bent in his Life Histories of North American Shore Birds, says of the Hudsonian Godwit: "I can count on the fingers of one hand the red-letter days when I have been privileged to see this rare and handsome wader. Many ornithologists have never seen it in life." Audubon never saw the bird.

On the same visit to Waterhen Marsh I flushed a Mallard from her nest. She fluttered off a few feet, turned around and snapped her bill at me. Then she went back on her nest and stayed there while Mrs. McKim watched her from a distance of about five feet.

\section{Appreciation}

Mrs. R. Gertrude Tatlow, Kinistino.

I WAS DEEPLY impressed when reading the BLUE JAY and am certainly going to encourage my youngsters to study its contents too. I firmly agree with one writer who believes every school library should contain this valuable and informative booklet.

I was especially interested in reading Judge McKim's write-up on the tame pheasant in Melfort. Some time ago the Melfort Journal reported the beheaded body of this tame pheasant had been found by a Melfort school girl and it was believed that bird's head had been cut off by a car or truck chain when the bird chased after the wheels of the vehicle. A sorry ending to such a lovely specimen of nature.

I am also interested in Indian lore, especially because the old Kinistino fort was located on this farm during the rebellion of 1885 . At present I am attempting to obtain as much information as possible about the fort for a Community History which is being compiled by our Crompton Homemakers' Club.

\section{Whooping Cranes}

Lloyd T. Carmichael

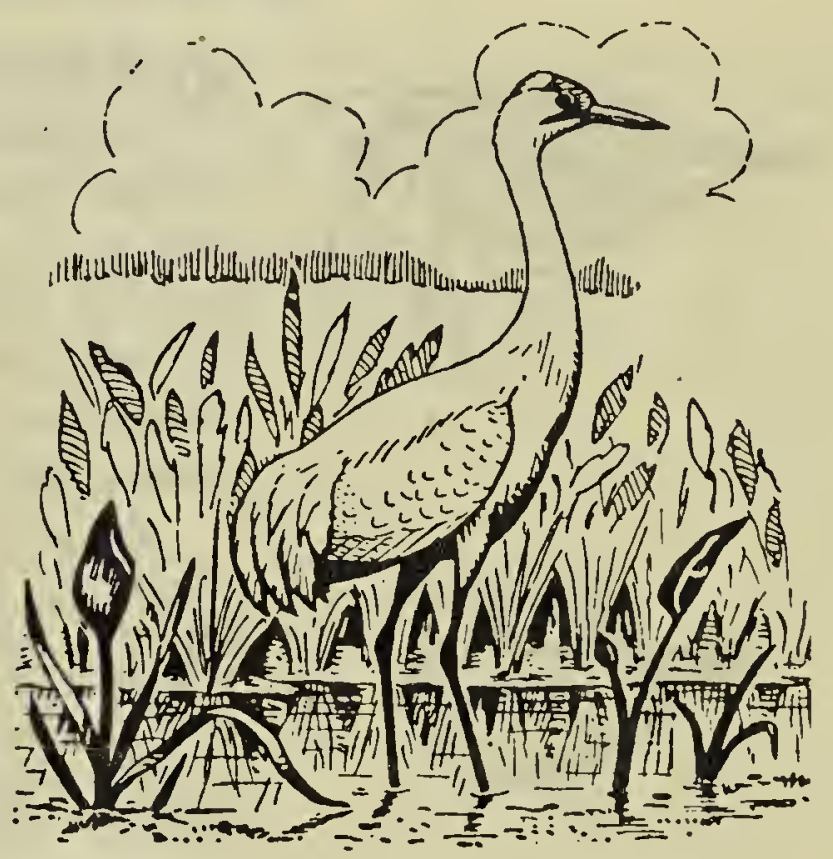

1 EW OF US, during recent years,

have had the thrill and pleasure of seeing one of these lovely birdsthere are less than three dozen in existence. Mrs. Carmichael, my son Garnet and I have had that privilege, not once, but twice.

We were driving along Highway 15 , about three miles south and a little west of Bounty on the 5 th of May. There to the south of the highway about a quarter of a mile, wading around contentedly in a temporary slough in a stubble field, were two of these birds. Through the strong field glasses, that we had, we could distinctly see their distinguishing characteristics $-\mathrm{t} h \mathrm{e}$ darkened cap ( we could not distinguish the dull red), the face streak which runs back under the eye and the black primaries on the wing. The birds must have been four feet high. As if to display its grandeur, one of them spread its wings and seemed to shake itself.

The next day as we were returning home, the same two birds were still out there in the unsheltered and wide open spaces for all to see and admire.

"Anything you love is a joy and a care-

Lilies in vases; a little girl's hair.

Both you must water, both you must tend,

Home and garden, family and friend: All that you love are forever needing, Heeding, seeding, weeding, feeding." 